\title{
Helminth Parasites of the Pelophylax esculentus Complex (Anura: Ranidae) in Hortobágy National Park (Hungary)
}

Author(s): Dávid Herczeg, Judit Vörös, Zsolt Végvári, Yuriy Kuzmin, and Daniel R. Brooks

Source: Comparative Parasitology, 83(1):36-48.

Published By: The Helminthological Society of Washington

URL: http://www.bioone.org/doi/full/10.1654/1525-2647-83.1.36

BioOne (www.bioone.org) is a nonprofit, online aggregation of core research in the biological, ecological, and environmental sciences. BioOne provides a sustainable online platform for over 170 journals and books published by nonprofit societies, associations, museums, institutions, and presses.

Your use of this PDF, the BioOne Web site, and all posted and associated content indicates your acceptance of BioOne's Terms of Use, available at www.bioone.org/page/ terms of use.

Usage of BioOne content is strictly limited to personal, educational, and non-commercial use. Commercial inquiries or rights and permissions requests should be directed to the individual publisher as copyright holder. 


\title{
Helminth Parasites of the Pelophylax esculentus Complex (Anura: Ranidae) in Hortobágy National Park (Hungary)
}

\author{
Dávid Herczeg, ${ }^{1,6}$ Judit Vörös, ${ }^{2}$ Zsolt Végvári, ${ }^{3}$ Yuriy Kuzmin, ${ }^{4}$ and Daniel R. Brooks ${ }^{5}$ \\ ${ }^{1}$ MTA-DE “Lendület” Behavioural Ecology Research Group, University of Debrecen, 1 Egyetem-tér, Debrecen, H-4032, \\ Hungary (e-mail: herczegdavid88@gmail.com), \\ ${ }^{2}$ Hungarian Natural History Museum, 13 Baross utca, Budapest, H-1088, Hungary (e-mail: jvoros@nhmus.hu), \\ ${ }^{3}$ Department of Conservation Zoology, University of Debrecen - Hortobágy National Park Directorate, 2 Sumen Street, \\ Debrecen, H-4024, Hungary (e-mail: vegvari@hnp.hu), \\ ${ }^{4}$ Department of Parasitology, I. I. Schmalhausen Institute of Zoology, 15 Bogdan Khmelnitsky Street, Kyiv-30 01601 \\ Ukraine (e-mail: rhabdias@gmail.com), and \\ ${ }^{5}$ H. W. Manter Laboratory of Parasitology, University of Nebraska State Museum of Natural History, University of \\ Nebraska, W 529 Nebraska Hall, Lincoln, Nebraska 68588-0514, U.S.A. (e-mail: dnlbrooks@gmail.com)
}

ABSTRACT: The Document, Assess, Monitoring, Act (DAMA) protocol details an approach to integrating information about parasites into large-scale studies of biodiversity, climate change, and emerging diseases. This study represents an effort to put the DAMA protocol into practice. We collected 101 individuals of protected ranid frogs belonging to the Pelophylax esculentus complex during 2012 and 2013 in the Hortobágy National Park (HNP) in eastern Hungary in an area where an inventory of amphibian helminths had been conducted $40 \mathrm{yr}$ previously. Collecting sites included flowing water, a fish pond system, and a wetland marsh system. We found the following helminth species: Digeneans: Diplodiscus subclavatus, Haematoloechus variegatus, Opisthioglyphe ranae, Pleurogenes claviger, Pleurogenoides medians; Nematodes: Oswaldocruzia filiformis, Rhabdias esculentarum; and Acanthocephala: Acanthocephalus ranae. Rhabdais esculentarum is a new species for the Hungarian fauna and $P$. ridibundus represents a new host record for $R$. esculentarum while D. subclavatus, $P$. claviger, and $P$. medians are new species for the helminthofauna of the HNP. Our findings showed a significant discrepancy from the results of baseline inventories carried out $40 \mathrm{yr}$ ago, although the reasons for this discrepancy are not clear. We suspect that the previously reported helminth species that we did not encounter are restricted to Pelophylax lessonae, a host we have not yet collected at this location, but factors associated with climate change or anthropogenic impacts cannot be ruled out.

KEY WORDS: Helminths of amphibians, Pelophylax ridibundus, Pelophylax esculentus, Digenea, Nematoda, Acanthocephala, Rhabdias esculentarum, Hungary.

For more than a decade, researchers have made the case that parasites should occupy a central role in our efforts to monitor changes in ecosystem structure emerging from global climate change, for detecting the potential for emerging diseases, and for changes in the colonization of human, livestock, or wildlife hosts (Brooks and Hoberg, 2000, 2006, 2013; Daszak et al., 2000; Agosta et al., 2010; Hoberg and Brooks, 2013; Brooks et al., 2014). To accomplish this it is thought that traditional faunal surveys of parasites must be brought back to center stage, but within a novel conceptual framework (Brooks et al., 2014). Traditional parasitological inventories of helminths aim to collect as many parasites from as many hosts as possible-especially hosts that have not been examined for parasites previously-gathering both taxonomic, ecologic, and population data from that extensive destructive sampling. In many cases today, however, the rationale for any such inventory

\footnotetext{
${ }^{6}$ Corresponding author.
}

encompasses host species of interest from the perspective of emerging diseases and biodiversity loss. Such hosts, however, often comprise vulnerable populations. Laws and regulations minimizing destructive sampling are aimed at maintaining populations of threatened or endangered animal and plant species in their natural habitats in the face of the current accelerated loss of biodiversity. However, collecting for such a scientific purpose is by no means the greatest threat to such populations (Minteer et al., 2014), and rapidly expanding urbanization, environmental pollution, habitat loss, fragmentation, and emerging infectious diseases pose greater threats (Blaunstein et al., 1994; Berill et al., 1997; Berger et al., 1998; Daszak et al., 1999; Corn, 2000; Cushman, 2006). Nonetheless, the paradoxical notion that parasitologists are "killing animals to save them" is deeply entrenched, leading to the paradox that many researchers desire information about the parasites of their hosts yet do not support inventory activities aimed at obtaining such data. If parasitologists believe that their inventory activities are justified, they need 
to advocate an approach that obviates such knee-jerk reactions by both the public and the scientific community in order to maximize and most efficiently obtain information pertaining to biodiversity.

Brooks et al. (2014) summarized a protocol (Document, Assess, Monitor, Act) with the acronym DAMA in reference to the above-noted need to sample threatened host species, suggesting that their integrated approach provides a proactive capacity to understand, anticipate, and respond to the outcomes of accelerating environmental change and its impact on parasitic and other diseases. While such an approach involves destructive sampling, the DAMA approach suggests that it is not necessary to kill large numbers of hosts to obtain important information about parasite biodiversity. In short, much more important is having and maximizing information available about each species collected (Brooks and Hoberg, 2000). For example, information about parasite transmission dynamics provides critical information about trophic structure in ecosystems (Marcogliese and Cone, 1997; Marcogliese, 2005), and much of that information can now be obtained using nondestructive sampling.

Within the DAMA approach Brooks (1998), and Brooks and Hoberg (2000), suggest that if a host is rare in the inventory site, then fewer hosts should be sampled. If a host is rare and endemic over it is entire geographic range, the option exists to not perform destructive sampling; in such cases, information can still be obtained based upon what is found in phylogenetically or ecologically (or both) related host species in the same area (Brooks and McLennan, 2002).

Such a destructively minimalist approach involves collecting voucher specimens of each species of parasite encountered, along with their deposition in properly curated museum collections to maximize biodiversity information (Davis, 1996; Global Taxonomy Initiative, 1999), in order to provide important historical data and predictive baselines for understanding the patterns and distribution of organisms. This implies that the infrastructure for collections must be regarded as an integral component of any developing program to survey, inventory, and document biodiversity resources, and such voucher specimens become essential references for future nondestructive sampling within the context of the assessment and monitoring elements of DAMA.

Much of the previous work on anuran helminths has focused on faunistic inventories based upon collections taken during a single season. In this study we compare our faunistical findings with historical baselines set up 4 decades ago (Edelényi, 1972;
Murai et al., 1983). While information derived from such long-term study allows the determination of the persistence and stability of parasite diversity (Bursey et al., 2010), the DAMA protocol departs from traditional surveys by suggesting that destructive sampling ends with this initial documentation phase. In this light we collected parasite material not just for classical morphology-based taxonomic indentification, but the majority of the helminth specimens were preserved in ethanol for the development of DNA barcodes (unpublished data). Methods such as DNA barcoding have the potential to provide quick and cost-effective ways to monitor parasite species and their transmission dynamics (Moszczynska et al., 2009; Locke et al., 2010, 2011; Prosser et al., 2013) and thus can be used as a baseline for future nondestructive study within the monitoring phase of DAMA using, for example, host feces, urine, or both. While such an approach precludes the possibility of obtaining direct documentation of statistically robust population estimates (noting that such data are part of the assessment phase in the DAMA protocol), such data can be obtained using noninvasive methods-with a caveat. At present, nondestructive sampling of parasites allows only the determination that at least 1 specimen of a given species of parasite is present in a host; hence, there is a critical need to develop better quantitative assessments of parasite loads based on data obtained from noninvasive methods.

The Hortobágy National Park (HNP) was founded in 1973 and is the largest contiguous alkaline steppe in Europe, covering 80,000 ha, and is the largest and oldest national park in Hungary. Approximately $30 \%$ of HNP is covered by wetlands including alkaline marshes, wet grasslands, and 75 fish ponds that cover 6,000 ha. The importance of HNP in sustaining wetland wildlife is recognized by the Ramsar Convention, designating 27,000 ha of the national park as Ramsar sites (Ecsedi, 2004).

Inventory data for helminths inhabiting amphibians in the HNP had been reported earlier by Edelényi (1972) and Murai et al. (1983). As in earlier studies of helminths of European amphibians (e.g., Buchvarov, 1962; Kuc and Sulgostowska, 1988a; Düsen and Öz, 2006; Popiolek et al., 2011), the hosts for most of the helminths previously reported from the amphibians of HNP are water frogs of the Pelophylax esculentus complex. Therefore we focused on those hosts in this study.

Systematists have begun untangling the complex evolutionary history of the P. esculentus complex. In 
the process, they have cast doubt on many host identifications in older studies for which no voucher specimens (of hosts or parasites) exist, thus making comparisons with recent studies difficult. For example, Dely (1981) mentioned 2 members of the $P$. esculentus complex as occurring in HNP, Pelophylax ridibundus (Pallas, 1771) and Pelophylax esculentus (Linnaeus, 1758), the latter of which originates from the hybridization of $P$. ridibundus and Pelophylax lessonae (Camerano, 1882) (see Graf and Polls-Pelaz, 1989). Mészáros and Bartos (1978) and Hilbers (2008) recently reported $P$. lessonae from HNP as well. No voucher specimens exist for the Pelophylax spp. listed as hosts by Edelényi (1972) and Murai et al. (1983).

In this report we follow the DAMA protocol and present findings documenting the helminth fauna of water frogs in the HNP in eastern Hungary while discussing initial efforts in assessing that fauna with respect to previous studies (Edelényi, 1972; Murai et al., 1983).

\section{MATERIALS AND METHODS}

\section{Study site}

We collected water frogs from habitats associated with flowing water $\left(47^{\circ} 26^{\prime} 43^{\prime \prime} \mathrm{N} ; 21^{\circ} 10^{\prime} 10^{\prime \prime} \mathrm{E}\right.$ and $47^{\circ} 26^{\prime} 38^{\prime \prime} \mathrm{N}$; $\left.21^{\circ} 08^{\prime} 26^{\prime \prime} \mathrm{E}\right)$, the fish pond system $\left(47^{\circ} 37^{\prime} 13^{\prime \prime} \mathrm{N} ; 21^{\circ} 04^{\prime}\right.$ $\left.35^{\prime \prime} \mathrm{E}\right)$, and marshland sites $\left(47^{\circ} 36^{\prime} 03^{\prime \prime} \mathrm{N} ; 20^{\circ} 52^{\prime} 53^{\prime \prime} \mathrm{E}\right)$ in the HNP.

\section{Data collection}

In many countries, including Hungary, all amphibian species are protected-some of them highly protected-and the collection of these individuals is strictly connected to research permits issued by the local authorities. These permits allow destructive sampling of a restricted number of individuals, which in most cases is not sufficient for assessing and monitoring parasite species. Water frogs were manually collected between May 2012 and August of 2013 using dip nets and by collecting fresh road kills. We collected 52 Pelophylax spp. individuals from 2 localities associated with flowing water (canals) and 49 individuals from Hortobágy fish ponds and the Egyek-Pusztakócs marsh system. Due to the high rate of hybridization among water frogs, we used molecular taxonomic techniques following the methods of Hauswaldt et al. (2012) to distinguish between $P$. ridibundus, $P$. lessonae, and the hybrid $P$. esculentus. This method is based on the PCR product size differences from the amplification of the serum albumin intron-1 gene fragment.

\section{Preparation and fixation methods}

We examined hosts for helminth parasites within $48 \mathrm{hr}$ of capture. The frogs were overanaesthetized in ether-filled glass containers and the body cavity opened via longitudinal ventral incision. The heart, lungs, liver, gall bladder, and urinary bladder were separated and examined under a stereomicroscope. The alimentary tract was opened by cutting from the anterior esophagus to the rectum and the contents placed into Petri dishes containing Ringer's solution and examined under a stereomicroscope. All helminths collected for DNA data were placed in $96 \% \mathrm{EtOH}$ for storage. Voucher specimens of adult digeneans were fixed in hot $4 \%$ formalin and stored in $70 \% \mathrm{EtOH}$. Nematodes were fixed in glacial acetic acid, washed in $70 \% \mathrm{EtOH}$, and stored in $70 \% \mathrm{EtOH}+$ $5 \%$ glycerine. Acanthocephalans were relaxed in distilled water for $24 \mathrm{hr}$ followed by fixation in alcohol formalin-acetic acid (AFA) for $24 \mathrm{hr}$ and then stored in $70 \% \mathrm{EtOH}$ Digeneans and acanthocephalans were stained with acetocarmine, dehydrated, cleared in cedar oil, and mounted in Damar gum. Nematodes were cleared in glycerol and examined as temporary mounts. Voucher specimens of parasites were deposited in the Parasitological collection and hosts were deposited to the Herpetological collection of the Hungarian Natural History Museum. Additional voucher specimens of Rhabdias esculentarum were deposited in the Helminthological collection of the Department of Parasitology, I. I. Schmalhausen Institute of Zoology, Kyiv, Ukraine.

\section{Statistical analysis}

We used generalized linear models (GLM) with a binomial error distribution term to determine the overall prevalence differences between sexes, host species, and collection sites. We used GLM with a Poisson error distribution term to determine the overall mean intensity of parasite species per hosts and for comparison of the previously mentioned variables. Based on the characteristics of collection sites, we pooled the data derived from the fish ponds and the EgyekPusztakócs marsh system, yielding 2 categories: habitats associated with still water (fish ponds and Egyek-Pusztakócs marsh system) and canals. Statistical analysis was carried out with QP. 3.0 (Rózsa et al., 2000) and in the R statistical environment (R Core Team, 2013). Overall prevalence and overall mean intensity data are followed by $95 \%$ confidence intervals; measurement data is presented as mean followed by minimum and maximun values in parentheses.

\section{RESULTS}

Table 1 summarizes our helminth findings for the 101 individuals (48 males and 53 females) of $P$. ridibundus and $P$. esculentus we collected. The overall prevalence of endoparasitic helminths was $76.2 \%(95 \%$ CI $=66.89-83.78)$ in the examined water frog population. The overall mean intensity was $2.44(95 \%$ CI $=2.17-2.71)$ helminth species per host. No host contained more than 6 species of parasites: $20(19.8 \%)$ of 101 Pelophylax spp. harbored 1 species, $24(23.8 \%)$ harbored 2 species, $19(18.8 \%)$ harbored 3 species, $9(9 \%)$ harbored 4 species, $3(3 \%)$ harbored 5 species, and $2(2 \%)$ harbored 6 species. We found that $P$. ridibundus individuals inhabiting canals had a significantly greater overall mean intensity of helminth species per host than did the same species in still water $\left(\chi^{2}=-4.782\right.$, df $\left.=1, P=0.002\right)$. No other significant differences were detected. Based upon these data we divided our faunistical findings 
Table 1. Species of parasites collected in this study from the Hortobágy National Park, Hungary.*

\begin{tabular}{lllll}
\hline \multicolumn{1}{c}{ Species } & \multicolumn{1}{c}{ Family } & \multicolumn{1}{c}{ Host record } & Location & Collection number \\
\hline Haematoloechus variegatus & Haematoloechidae Freitas \& Lent, 1939 & P. ridibundus, P. esculentus & lungs & NHMH-18465 \\
Opisthioglyphe ranae & Telorchiidae Looss, 1899 & P. ridibundus, P. esculentus & SI, LI & NHMH-18463 \\
Diplodiscus subclavatus & Diplodiscidae Cohn, 1904 & P. ridibundus, P. esculentus & rectum & NHMH-18464 \\
Pleurogenes claviger & Pleurogenidae Looss, 1899 & P. ridibundus & SI & NHMH-18461 \\
Pleurogenoides medians & Pleurogenidae Looss, 1899 & P. ridibundus, P. esculentus & SI, LI & NHMH-18462 \\
Oswaldocruzia filiformis & Trichostrongylidae Leiper, 1912 & P. ridibundus & SI & NHMH-18466 \\
Rhabdias esculentarum & Rhabdiasidae Railliet, 1915 & P. ridibundus, P. esculentus & lungs & NN 6.1, NN 6.2, NN 6.3, NN 6.4 \\
Acanthocephalus ranae & Echinorhynchidae Cobbold, 1879 & P. ridibundus, P. esculentus & SI & NHMH-18467 \\
\hline
\end{tabular}

* SI = small intestine; $\mathrm{LI}=$ large intestine; NHMH = Parasitological collection, Hungarian Natural History Museum, Budapest, Hungary; $\mathrm{NN}=$ Helminthological collection, Department of Parasitology, I. I. Schmalhausen Institute of Zoology, Kyiv, Ukraine. All specimens were adults.

into 3 categories: Persistent core species; Missing species; and Species new to the area.

\section{Persistent core species}

Digenea: Haematoloechus variegatus (Rudolphi, 1819) Looss, 1899; Opisthioglyphe ranae (Frölich, 1791) Looss, 1899; Nematoda: Oswaldocruzia filiformis (Goeze, 1782); and Acanthocephala: Acanthocephalus ranae (Schrank, 1788) Lühe, 1911. These species were reported in HNP previously and are commonly reported species in European amphibians. Consequently, these species seem to form a strong and persistent core of parasite species in the anurans of HNP.

\section{Missing species}

These helminths were reported in previous studies, were confirmed by examination of deposited voucher specimens, and were absent from our inventory. Digenea: Codonocephalus urnigerus (Rudolphi, 1819) metacercaria; Clinostomum complanatum (Rudolphi, 1814) metacercaria; Cephalogonimus retusus (Dujardin, 1845) Odhner, 1910; Gorgodera cygnoides (Zeder, 1800) Looss 1899; Haplometra cylindracea (Zeder, 1800) Looss, 1899; Haematoloechus asper (Looss, 1899); Pleurogenes loossi (Looss, 1890) Africa, 1930; and Nematoda: Cosmocerca ornata (Dujardin, 1845).

\section{Species new to the area
Diplodiscus subclavatus (Pallas, 1760) Diesing, 1836

Description $(n=3)$ : Body pyramidal, 3.8 (2.7-5.7) $\mathrm{mm}$ long and $1.83(1.1-2.6) \mathrm{mm}$ wide. Oral sucker terminal $0.43(0.3-0.6) \mathrm{mm}$ wide with well developed oral diverticula. Oesophageal bulb 0.45 (0.35-0.6) $\mathrm{mm}$ long and $0.56(0.4-0.9) \mathrm{mm}$ in diameter.
Acetabulum terminal and large with central accessory sucker. Acetabulum 1.93 (1.2-2.5) mm wide and one third of the total body length.

Site of infection: Rectum.

Type host and type locality: Rana spp., Germany (Goeze, 1782).

Other reported hosts and geography: European fire-bellied toad, Bombina bombina (Vojtková, 1961, former Czechoslovakia; Vojtková et al., 1963, former Czechoslovakia; Kozák, 1966, former Czechoslovakia; Vojtková and Krivanec, 1970, former Czechoslovakia); yellow-bellied toad, Bombina variegata (Kozák, 1966, former Czechoslovakia; Prokopic and Krivanec, 1975, former Czechoslovakia); common toad, Bufo bufo (Vojtková, 1961, former Czechoslovakia; Sey, 1964, 1968, Hungary; Kozák, 1973, former Czechoslovakia; Sey, 1991, Hungary; Cox, 1971, United Kingdom; Shimalov and Shimalov, 2001, Belarus); European green toad, Bufo viridis (Sey, 1964, 1968, 1991, Hungary; Vashetko and Siddikov, 1999, Uzbekistan; Murvanidze et al., 2008, Georgia); European tree-frog, Hyla arborea (Vojtková, 1961, former Czechoslovakia); lemon-yellow tree frog, Hyla savignyi (Yildirimhan et al., 2012, Turkey); edible frog, Pelophylax esculentus (Edelényi, 1942, 1960, Hungary; Sey, 1964, 1968, Hungary; Popovic and Mikes, 1989, Serbia; Sey, 1991, Hungary; Bjelic-Cabrilo et al., 2009, Serbia; Chikhlaev et al., 2009, Russia; Popiolek et al., 2011, Poland); pool frog, Pelophylax lessonae (Vojtková, 1961, former Czechoslovakia; Vojtková et al., 1963, former Czechoslovakia; Kuc and Sulgostowska, 1988b, Poland; Bakhoum et al., 2011, Belarus; Popiolek et al., 2011, Poland); marsh frog, Pelophylax ridibundus (Edelényi, 1960, Hungary; Buchvarov, 1962, Bulgaria; Sey, 1964, Hungary; Popovic and Mikes, 1989, Serbia; Sey, 1991, Hungary; Yildirimhan et al., 1996, Turkey; Düsen and Öz, 2006, Turkey; Murvanidze et al., 2008, 
Georgia; Popiolek et al., 2011, Poland); Pelophylax spp. (Sey, 1983; Sey and Eöry, 1992, Hungary); moor frog, Rana arvalis (Kozák, 1973, former Czechoslovakia; Sey, 1991, Hungary); agile frog, Rana dalmatina (Kozák, 1973, former Czechoslovakia); Uludağ frog, Rana macrocnemis (Murvanidze et al., 2008, Georgia); common frog, Rana temporaria (Bovien, 1916, Denmark; Vojtková et al., 1963, former Czechoslovakia; Kozák, 1966, former Czechoslovakia; Prokopic and Krivanec, 1975, former Czechoslovakia; Kuc and Sulgostowska, 1988b, Poland; Sey, 1991, Hungary); alpine newt, Ichthyosaura alpestris (Barus et al., 1963, former Czechoslovakia); common newt, Lissotriton vulgaris (Prokopic and Krivanec, 1975, former Czechoslovakia; Cedhagen, 1988, Sweden; Bertman, 1994, Poland); northern crested newt, Triturus cristatus (Barus et al., 1963, former Czechoslovakia; Vojtková, 1963, former Czechoslovakia; Frandsen, 1974, Denmark; Bertman, 1994, Poland); sand lizard, Lacerta agilis (Lewin, 1992, Poland); European grass snake, Natrix natrix (Sey, 1991, Hungary; Bertman, 1993, Poland; Buchvarov et al., 2000, Bulgaria; Shimalov and Shimalov, 2000, Belarus; Murvanidze et al., 2008, Georgia); dice snake, Natrix tessellata (Buchvarov et al., 2000, Bulgaria); nose-horned viper, Vipera berus (Shimalov and Shimalov, 2000, Belarus).

Specimens deposited and collection numbers: One, deposited in the Parasitological Collection of the Hungarian Natural History Museum (NHMH-18464).

\section{Remarks}

Previous reports from HNP did not mention the presence of this digenean species even though $D$. subclavatus is a common and widely distributed endoparasite of amphibians throughout Europe. Members of Diplodiscus in Eurasia and closely related North American (Megalodiscus) and Neotropical (Catadiscus) representatives of the Paramphistomidae are among the most-commonly reported anuran digeneans.

\section{Pleurogenes claviger (Rudolphi, 1819) Looss, 1896}

Site of infection: Small intestine.

Type host and type locality: Bufo viridis (Laurenti, 1768), Europe (Rudolphi, 1819).

Other reported hosts and geography: Bufo bufo (André, 1912, Switzerland; Cox, 1971, United Kingdom; Frandsen, 1974, Denmark; Cedhagen, 1988, Sweden); Bufo viridis (Shimalov and Shimalov, 2001, Belarus); Natrix natrix (Mihalca et al., 2007, Romania); Pelophy- lax esculentus (André, 1913, Switzerland; Edelényi, 1942, Hungary; Sey, 1964, 1968, Hungary; Cox, 1971, United Kingdom; Frandsen, 1974, Denmark; Kuc and Sulgostowska, 1988b, Poland; Chikhlaev et al., 2009, Russia; Bjelic-Cabrilo et al., 2009, Serbia); Pelophylax ridibundus (Sey, 1964, Hungary; Combes and Gerbeaux, 1970, Spain; Kuc and Sulgostowska, 1988a, Poland; Sey and Eöry, 1992, Hungary; Oguz et al., 1994, Turkey; Yildirimhan et al., 1996, Turkey); Pelophylax spp. (Sey and Eöry, 1992, Hungary); Rana arvalis (Sey, 1964, Hungary); Rana macrocnemis (Yildirimhan et al., 1997; Yildirimhan, Bursey et al., 2006, Turkey); Rana temporaria (André, 1913, Switzerland; Bovien, 1916, Denmark; Cox, 1971, United Kingdom; Frandsen, 1974, Denmark; Cedhagen, 1988, Sweden; Tkach et al., 2000, Ukraine); Lacerta agilis (Sharpilo et al., 2001, Ukraine).

Specimens deposited and collection numbers: One, deposited in the Parasitological Collection of the Hungarian Natural History Museum (NHMH-18461).

\section{Remarks}

Previous reports from HNP did not mention the presence of this digenean species. A few reports from Hungary exist but their occurence is not frequent. We found only 1 specimen in the small intestine of $P$. ridibundus collected from canals and could not generate measurements because of the poor condition of the only available voucher specimen.

\section{Pleurogenoides medians (Olsson, 1876) Travassos, 1921}

Description ( $n=5)$ : Body elongate, 81.2 (65-94) $\mu \mathrm{m}$ long and $50(35-65) \mu \mathrm{m}$ wide. Oral sucker is subterminal and round, 15 (10-20) $\mu \mathrm{m}$ in diameter. The ventral sucker is round, $12.6(12-13) \mu \mathrm{m}$ in diameter. The testes are symmetrical, posterior to the cecum, $10(9-11) \mu \mathrm{m}$ in diameter. The ovary is elongate, lateral to the cecum in the left side, 11.5 (9-14) $\mu \mathrm{m}$ long and 7 (6-8) $\mu \mathrm{m}$ wide.

Site of infection: Small and large intestines.

Type host and type locality: B. viridis, Denmark (Olsson, 1876).

Other reported hosts and geography: Bombina bombina (Vojtková, 1961, former Czechoslovakia; Vojtková et al., 1963, former Czechoslovakia; Vojtková and Vojtek, 1975, former Czechoslovakia); Bombina variegata (Vojtková and Vojtek, 1975, former Czechoslovakia); Bufo bufo (Cox, 1971, United Kingdom; Kozák, 1973, former Czechoslovakia; 
Vojtková and Vojtek, 1975, former Czechoslovakia; Fernandez et al., 1986, Spain; Shimalov and Shimalov, 2001, Belarus); Bufo viridis (Kolendo, 1959, Poland; Vojtková and Vojtek, 1975, former Czechoslovakia); natterjack toad, Epidalea calamita (Vojtková and Vojtek, 1975, former Czechoslovakia); Hyla arborea (Kozák, 1973, former Czechoslovakia; Vojtková and Vojtek, 1975, former Czechoslovakia; Düsen and Öz, 2004, Turkey); Pelophylax esculentus (Edelényi, 1942, 1960, Hungary; Sey, 1964, Hungary; Rodrigues et al., 1973 Portugal; Popovic and Mikes, 1989, Serbia; Chikhlaev et al., 2009, Russia); Pelophylax lessonae (André, 1913, Switzerland; Bovien, 1916, Denmark; Kopriva, 1957, former Czechoslovakia; Vojtková, 1961, former Czechoslovakia; Vojtková et al., 1963, former Czechoslovakia; Kozák, 1966, 1968, former Czechoslovakia; Sey, 1968, Hungary; Kozák, 1973, former Czechoslovakia; Vojtková and Vojtek, 1975, former Czechoslovakia; Buchvarov, 1977, Bulgaria; Kuc and Sulgostowska, 1988b, Poland; Tkach et al., 2003, Ukraine; Bjelic-Cabrilo et al., 2009, Serbia); Pelophylax ridibundus (Edelényi, 1960, Hungary; Buchvarov, 1962, 1977, 1983, Bulgaria; Combes and Gerbeaux, 1970, Spain; Cox, 1971, United Kingdom; Kozák, 1973, former Czechoslovakia; Kuc and Sulgostowska, 1988a, Poland; Popovic and Mikes, 1989, Serbia; Oguz et al., 1994, Turkey; Yildirimhan et al., 1996, Turkey; Hassan and Saeed, 2001, Iraq; Düsen and Öz, 2006, Turkey; Saglam and Arikan, 2006, Turkey; Murvanidze et al., 2008, Georgia); Pelophylax spp. (Sey and Eöry, 1992, Hungary); Rana arvalis (Kozák, 1973, former Czechoslovakia; Vojtková and Vojtek, 1975, former Czechoslovakia); Rana dalmatina (Kozák, 1973, former Czechoslovakia; Prokopic and Krivanec, 1975, former Czechoslovakia; Buchvarov, 1977, Bulgaria; Düsen et al., 2009, Turkey); Rana macrocnemis (Yildirimhan, Bursey et al., 2006, Turkey; Düsen, 2007, Turkey; Murvanidze et al., 2008, Georgia); Rana temporaria (Bovien, 1916, Denmark; Kopriva, 1957, former Czechoslovakia; Vojtková and Krivanec, 1970, former Czechoslovakia; Prokopic and Krivanec, 1975, former Czechoslovakia; Vojtková and Vojtek, 1975, former Czechoslovakia; Cedhagen, 1988, Sweden); Lissotriton vulgaris (Vojtková, 1963, former Czechoslovakia); Triturus cristatus (Vojtková, 1963, former Czechoslovakia); Lacerta agilis (Lewin, 1992, Poland; Sharpilo et al., 2001, Ukraine); Natrix tessellata (Buchvarov et al., 2000, Bulgaria).

Specimens deposited and collection numbers: One, deposited in the Parasitological Collection of the Hungarian Natural History Museum (NHMH-18462).

\section{Remarks}

This is a new record for HNP. It has been reported previously in water frogs from Hungary (Edelényi, 1942, 1960; Sey, 1964, 1968; Sey and Eöry, 1992).

\section{Rhabdias esculentarum (Cipriani, Mattiucci, Paoletti, Santoro and Nascetti, 2012)}

Description $(n=4)$ : Body small, 4.99 (4.34-6.41) mm long, 283 (268-304) $\mu \mathrm{m}$ wide (maximum width at vulval region). Body cuticle partly inflated, especially at the anterior and posterior ends. Buccal capsule wide, 9 (8-10) $\mu \mathrm{m}$ depth, 12.25 (8-14) $\mu \mathrm{m}$ outer diameter, $10 \quad(9-13) \mu \mathrm{m}$ inner diameter. Oesophageal length 389.5 (362-433) $\mu \mathrm{m}$ (7.9\% of total body length), width 27.5 (26-30) $\mu \mathrm{m}$ at anterior end, 61.75 (57-65) $\mu \mathrm{m}$ at oesophageal bulb. Nervering near middle of oesophagus. Vulva postequatorial, distance from anterior end to vulva 2,759.5 $(2,209-3,581) \mu \mathrm{m}$. Tail simple and pointed, length 205.5 (183-240) $\mu \mathrm{m}$ (4.16\% total body length).

\section{Site of infection: Lungs.}

Type host and type locality: Pelophylax lessonae, Lake Vico, Latium, central Italy (Cipriani et al., 2012).

Other reported hosts and geography: Pelophylax esculentus (Cipriani et al., 2012, Italy).

Specimens deposited and collection numbers: Four, deposited in the Helminthological collection of the Department of Parasitology, I. I. Schmalhausen Institute of Zoology (NN 6.1; NN 6.2; NN 6.3; NN 6.4).

\section{Remarks}

The shape of the anterior end, shape of the buccal capsule and oesophagus, and the presence of ventral inflation of the body wall posterior to the anus are the characters allowing the specimen to be assigned to $R$. esculentarum. Using these characters, these worms differ from Rhabdias bufonis (Schrank, 1788) Stiles and Hassall, 1905; from Pelophylax spp.; from Rhabdias rubrovenosa (Schneider, 1866) Semenov, 1929; and from Rhabdias sphaerocephala (Goodey, 1924), all of which are all known from European bufonids. Pelophylax ridibundus is a new host record for R. esculentarum and Hungary is a new geographic distribution record.

\section{DISCUSSION}

As suggested by Brooks et al. (2014), assessment in the DAMA protocol is a 2-part process. The first of these is comparison of data with baselines (i.e., what 
is already known about the parasites, hosts, and geographic location of an inventory) to address the question of how current findings relate to previous findings. The latter requires the understanding and acceptance that new inventories of places and hosts assessed previously are just as important, and possibly even more so, than are inventories of new hosts and new places. This study provides an excellent example of this assertion.

The current amphibian helminth fauna in the HNP appears to differ significantly from that reported previously by Edelényi (1972) and Murai et al. (1983). First, the original study of amphibian helminths in the HNP listed Pleurogenes loossi as present. We did not find this species but did find Pleurogenoides medians and Pleurogenes claviger.

Second, Murai et al. (1983) listed 3 species of digeneans inhabiting the lungs of water frogs: 2 species of Haematoloechus (H. variegatus and H. asper) and Haplometra cylindracea. In contrast, we found only $H$. variegatus in this study. All 3 species are historically common: $H$. variegatus has been found in Bulgaria (Buchvarov, 1977), Georgia (Murvanidze et al., 2008), Hungary (Edelényi, 1942, 1960; Sey, 1964, 1968; Murai et al., 1983; Sey and Eöry, 1992), Ukraine (Tkach et al., 2000), Poland (Kuc and Sulgostowska, 1988a, b; Popiolek et al., 2011), Portugal (Rodrigues et al., 1973), Russia (Chikhlaev et al., 2009), Serbia (Popovic and Mikes, 1989; Bjelic-Cabrilo et al., 2009), Turkey (Yildirimhan et al., 1996; Saglam and Arikan, 2006; Yildirimhan, Goldberg et al., 2006), and the United Kingdom (Cox, 1971). Haematoloechus asper has been reported from Georgia (Murvanidze et al., 2008), Hungary (Sey, 1964, 1968; Murai et al., 1983), Ukraine (Tkach et al., 2000), and Russia (Chikhlaev et al., 2009); and $H$. cylindracea has been reported from Belarus (Ryzhikov et al., 1980), Bulgaria (Buchvarov, 1977), former Czechoslovakia (Vojtková and Vojtek, 1975), Hungary (Murai et al., 1983), Iran (Mashaii, 2005), Latvia (Ryzhikov et al., 1980), Lithuania (Ryzhikov et al., 1980), Russia (Ryzhikov et al., 1980), Sweden (Cedhagen, 1988), Turkey (Yildirimhan, Bursey et al., 2006; Düsen, 2007, 2012), Ukraine (Ryzhikov et al., 1980; Tkach et al., 2000), and the United Kingdom (Cox, 1971).

Murai et al. (1983) also reported Cephalogonimus retusus and Cosmocerca ornata in the small intestine and Gorgodera cygnoides in the urinary bladder of water frogs in the HNP. Neither species was found in our study. All 3 species are common parasites of amphibians: $C$. retusus has been reported from
Armenia (Ryzhikov et al., 1980), Azerbaijan (Ryzhikov et al., 1980), Bulgaria (Buchvarov, 1977; Buchvarov et al., 2000), Georgia (Ryzhikov et al., 1980; Murvanidze et al., 2008), Hungary (Edelényi, 1942, 1960; Sey, 1968; Murai et al., 1983), Portugal (Rodrigues et al., 1973), Russia (Ryzhikov et al., 1980), Serbia (Popovic and Mikes, 1989), and the United Kingdom (Cox, 1971); and C. ornata has been reported from Belarus (Shimalov and Shimalov, 2001; Shimalov et al., 2000, 2001), Bulgaria (Buchvarov, 1977), Georgia (Murvanidze et al., 2008), Hungary (Murai et al., 1983), Iran (Mashaii, 2005), Italy (Galli et al., 2000, 2001), Poland (Kuc and Sulgostowska, 1988a, b; Grabda-Kazubska and Lewin, 1989; Popiolek et al., 2011), Russia (Chikhlaev et al., 2009), Sweden (Cedhagen, 1988), Turkey (Düsen and Öz, 2004, 2006; Yildirimhan, Bursey et al., 2006; Düsen, 2007), United Kingdom (Walton, 1933; Cox, 1971), and Uzbekistan (Vashetko and Siddikov, 1999). Gorgodera cygnoides has been reported from Azerbaijan (Ryzhikov et al., 1980), Belarus (Ryzhikov et al., 1980; Shimalov and Shimalov, 2001), Bulgaria (Buchvarov, 1977, 1983; Kirin, 2002), former Czechoslovakia (Vojtková and Vojtek, 1975), Georgia (Ryzhikov et al., 1980; Murvanidze et al., 2008), Greece (Hristovski et al., 2006), Hungary (Edelényi, 1942, 1960; Sey, 1964, 1968; Murai et al., 1983), Kyrgyzstan (Ryzhikov et al., 1980), Macedonia (Hristovski et al., 2006), Poland (Kuc and Sulgostowska, 1988a, b; Popiolek et al., 2011), Portugal (Rodrigues et al., 1973), Russia (Ryzhikov et al., 1980), Serbia (Popovic and Mikes, 1989), Tadzhikistan (Ryzhikov et al., 1980), Turkey (Yildirimhan et al., 1996; Düsen and Öz, 2006; Yildirimhan, Goldberg et al., 2006; Yildirimhan et al., 2009; Düsen and Oguz, 2010), Ukraine (Ryzhikov et al., 1980), United Kingdom (Cox, 1971), and Uzbekistan (Ryzhikov et al., 1980). The absence of $C$. retusus, $C$. ornata, $G$. cygnoides, $H$. asper, H. cylindracea, and $P$. loossi were confirmed by sampling in 2013 .

Murai et al. (1983) did not report members of 2 common amphibian helminth taxa that we detected, including nematodes belonging to the genus Rhabdias, which includes species living in the lungs of both amphibians and some lizards (Cipriani et al., 2012; Kuzmin, 2013). Most studies of Rhabdias in European amphibians have reported $R$. bufonis, and Edelényi (1960) reported this worm from P. esculentus, $P$. ridibundus, and Bufo viridis near the HNP. However, Murai et al. (1983) did not list any species of Rhabdias. Recent research suggests that specimens identified as $R$. bufonis represent a species complex 
(Tkach et al., 2014). Cipriani et al. (2012) recently described $R$. esculentarum from both $P$. lessonae and $P$. esculentus in Italy, and our specimens in water frogs from HNP correspond to that species. We have not collected parasites from Bufo bufo (Linnaeus, 1758 ) or $B$. viridis, so we do not know if both $R$. bufonis and $R$. esculentarum do, or did, co-occur in the HNP. If the report of $R$. bufonis in Pelophylax spp. by Edelényi (1960) actually referred to $R$. esculentarum, then $R$. esculentarum must be assigned to the group of persistent core species of helminths in the water frogs of HNP.

Interestingly, D. subclavatus occurs in the rectum of frogs throughout Europe. We are therefore surprised that neither Edelényi (1972) nor Murai et al. (1983) listed $D$. subclavatus. Given its widespread geographic and host range, we would expect this species to be 1 of the persistent core species as well.

If we provisionally assign $R$. esculentarum to the category of persistent core species, the changes in the helminth fauna of water frogs in HNP consists of the loss of 5 species of digenean, 1 species of nematode, and the addition of $D$. subclavatus. These species seem to have little in common with respect to their basic ecology: as a group they live in the rectum, small intestine, urinary bladder, and lungs. Their first intermediate hosts include both gastropods and bivalves, and their second intermediate hosts range from the surface of plants and the exoskeleton of crustaceans to odonate larvae and tadpoles.

One thing the missing species may have in common is their anuran host. Of the 3 members of the $P$. esculentus complex occurring in HNP, Edelényi (1972) and Murai et al. (1983) listed only $P$. ridibundus and $P$. esculentus as hosts, and all the missing helminth species were reported from these 2 species. Unfortunately, no vouchers of collected hosts were deposited, and it is possible that some of the hosts identified previously as $P$. ridibundus were actually $P$. esculentus or $P$. lessonae. In this study, we collected only $P$. ridibundus and $P$. esculentus, so it is tempting to suggest that the missing parasites still occur in the HNP but that they are restricted to $P$. lessonae, which we have not yet collected. Such an explanation leads to the question: Has this species experienced a decline, or even extirpation, in HNP?

The answer to the above question may be due to localized anthropogenic phenomena, incuding the effects of urbanization, agriculture, or both, which may have reduced or changed the composition of the invertebrate fauna necessary to maintain the transmission dynamics of the missing species of helminths and which may have allowed D. subclavatus, if it is truly new to HNP, to become established. Given the protected status of the study site, we do not believe that there have been such significant anthropogenic changes inside HNP, implying that regional effects, including climate change, may play an important role in this regard. At this higher level of assessment we would expect to see a geographic pattern distinguishing the species that have been lost from those that persist. However, at this level no such obvious patterns exist that might explain the differences in results between our study and the previous inventories.

Previous reports did not list information about the prevalence and intensity of infection, and all water frogs were identified as either Rana ridibunda $(=P$. ridibundus) or Rana esculenta ( $=P$. esculentus). It is possible that the missing parasites were quite rare in previous studies, and that they still exist as rare species today, which is supported by our finding of only a single specimen of $P$. claviger during $2 \mathrm{yr}$ of sampling. Alternatively, it is also possible that $P$. lessonae and the missing parasites were previously more common and that they have become rare in the HNP. We suggest that additional efforts be made to find and assess the status of $P$. lessonae, and their parasites, in the HNP.

A second class of baseline comparisons is evolutionary, via asking "Parascript" (Manter, 1966) questions about the phylogenetic context of the ecology and distribution of the parasites found in an inventory. Such data are rare, and not often applied to inventory studies in parasitology, despite a generation of calls for such action (e.g., Brooks and McLennan, 1993; Brooks, 1998; Brooks and Hoberg, 2000, 2006, 2007, 2013; Hoberg, 1997, 2010; Hoberg and Brooks, 2008, 2010, 2013; Hoberg et al., 2012, 2013; Brooks et al., 2014). Because the documentation phase of the DAMA protocol precludes the possibility of obtaining such direct documentation of statistically robust population estimates, our results must be considered highly preliminary, at best, given the small sample size necessitated by the constraints of collecting permits. Nevertheless, such population level data are a critical part of the assessment phase in the DAMA protocol and they can be obtained in the future using noninvasive methods that can provide both qualitative (presence-absence) and quantitative (relative abundance) data (e.g., Endo et al., 2009). As such, our data serve as a starting point and marker for the monitoring element of the HNP within the context of 
the DAMA protocol. Thus, while it may seem somewhat clumsy to undertake an inventory and monitoring project in separate phases, we believe that this approach maximizes the amount of information obtained while minimizing the amount of destructive sampling needed over the long term. In short, we believe that the DAMA protocol initiated herein provides an excellent means of obtaining useful information from parasite inventories (both within the HNP and elsewhere), even though limited destructive sampling occurs. The addition of molecular genetic data derived from parasites collected in this study will allow additional critical information to be gathered using nondestructive techniques in the future.

\section{ACKNOWLEDGMENTS}

The work is supported by the Társadalmi Megújulás Operatív Program (TÁMOP) -4.2.2/B-10/1-2010-0024 project. The project is cofinanced by the European Union and the European Social Fund. During the project, J.V. was financed by the Hungarian Scientific Research Fund (OTKA K77841). The authors are indebted to Virág Krízsik, Orsolya Márton, and Mária Tuschek in the Molecular Taxonomy Laboratory of the Hungarian Natural History Museum for their technical assistance. Furthermore, we are thankful to Attila Fülöp in the MTA-DE Lendület Behavioural Ecology Research Group who, with his useful insights, helped us progress with the data processing. We are also indebted to István Matskási from the Hungarian Natural History Museum who provided us the voucher specimens of parasites from previous surveys. Our research permit was allowed by the Tisza Region Inspectorate of Environment, Nature Conservation and Water Management (4633/ $\mathrm{OH} / 2012$ ).

\section{LITERATURE CITED}

Africa, C. M. 1930. Pleurogenes loossi sp. nov. in the intestine of water frogs (Rana esculenta). Zentralblatt für Bakteriologie, Parasitenkunde und Infektionskrankheiten. I. Abteilung 115:448-451.

Agosta, S. J., N. Janz, and D. R. Brooks. 2010. How generalists can be specialists: resolving the "parasite paradox" and implications for emerging disease. Zoologia 27:151-162.

André, E. 1912. Recherches parasitologiques sur les amphibiens de la Suisse. Revue Suisse de Zoologie 20:471-485.

André, E. 1913. Recherches parasitologiques sur les amphibiens de la Suisse. II. Revue Suisse de Zoologie 21:79-200.

Bakhoum, A. J. S., J. Torres, V. V. Shimalov, C. T. Ba, and J. Miquel. 2011. Spermiogenesis and spermato- zoon ultrastructure of Diplodiscus subclavatus (Pallas, 1760) (Paramphistomoidea, Diplodiscidae), an intestinal fluke of the pool frog Rana lessonae (Amphibia, Anura). Parasitology International 60:64-74.

Barus, V., J. Groschaft, and M. Otcenasek. 1963. Helmintofauna ocasatych obojzivelniku z uzemi Ceskolovenska. Vestnik Ceskoslovenske Spolecnosti Zoologicke 10:43-59.

Berger, L., R. Speare, P. Daszak, D. E. Green, A. A. Cunningham, C. L. Goggin, R. Slocombe, M. A. Ragan, A. D. Hyatt, K. R. McDonald, H. B. Hines, K. R. Lips, G. Marantelli, and H. Parkes. 1998. Chytridiomycosis causes amphibian mortality associated with population declines in the rain forests of Australia and Central America. Proceedings of the National Academy of Science 95:9031-9036.

Berrill, M., S. Bertram, and B. Pauli. 1997. Effects of pesticides on amphibian embryos and tadpoles. Pages 233-245 in D. M. Green, ed. Amphibians in Decline: Canadian Studies of a Global Problem. Society for the Study of Amphibians and Reptiles, St. Louis, Missouri.

Bertman, M. 1993. Diplodiscus subclavatus (Pallas, 1760) (Trematoda) and Acanthocephalus ranae (Schrank, 1788) (Acanthocephala) in grass snake-Natrix natrix (L.). Wiadomości Parazytologiczne 39:405-406.

Bertman, M. 1994. Parasites of the smooth newt-Triturus vulgaris L. and the crested newt-Triturus cristatus (Laur.) of the Tarnobrzeg voivodship. Wiadomości Parazytologiczne 40:93-97.

Bjelic-Cabrilo, O., E. Popovic, and A. Paunovic. 2009. Helminthofauna of Pelophylax kl. esculentus (Linné, 1758) from Petrovaradinski Rit Marsh (Serbia). Helminthologia 46:107-111.

Blaustein, A. R., D. B. Wake, and W. P. Sousa. 1994. Amphibian declines: judging stability, persistence, and susceptibility of populations to local and global extinctions. Conservation Biology 8:60-71.

Bovien, P. 1916. Forelobig meddelelse om forekomst og hyppighed af trematoder hos Rana esculenta og $R$. platyrrhinus. Videnskabelige meddelelser fra Dansk naturhistorisk forening i Kobenhavn 67:16-17.

Brooks, D. R. 1998. Triage for the biosphere. Pages 71-80 in G. B. Softing, G. Benneh, K. Hindar, and A. Wijkman, eds. The Brundtland Commission's Report-10 Years. Scandinavian University Press, Oslo, Norway.

Brooks, D. R., and E. P. Hoberg. 2000. Triage for the biosphere: the need and rationale for taxonomic inventories and phylogenetic studies of parasites. Journal of the Helminthological Society of Washington 67:1-25.

Brooks, D. R., and E. P. Hoberg. 2006. Systematics and emerging infectious diseases: from management to solution. Journal of Parasitology 92:426-429.

Brooks, D. R., and E. P. Hoberg. 2007. How will global climate change affect parasite-host assemblages? Trends in Parasitology 23:571-574.

Brooks, D. R., and E. P. Hoberg. 2013. The emerging infectious disease crisis and pathogen pollution: a question of ecology and evolution. Pages 215-229 in K. Rohde, ed. The Balance of Nature and Human Impact. Cambridge University Press, Cambridge, U.K.

Brooks, D. R., E. P. Hoberg, W. A. Boeger, S. L. Gardner, K. E. Galbreath, D. Herczeg, H. H. 
Mejía-Madrid, S. E. Rácz, and A. Tsogsaikhan. 2014. Finding them before they find us: informatics, parasites and environments in accelerating climate change. Comparative Parasitology 81:155-164.

Brooks, D. R., and D. A. McLennan. 1993. Parascript: Parasites and the Language of Evolution. Smithsonian Institution Press, Washington, D.C. 429 pp.

Brooks, D. R., and D. A. McLennan. 2002. The Nature of Diversity: An Evolutionary Voyage of Discovery. University of Chicago Press, Chicago, Illinois. 668 pp.

Buchvarov, G. K. 1962. Helminthofauna of the acaudate amphibians of the district of Plovdiv. Bulletin of the Central Helminthological Laboratory 7:103-111.

Buchvarov, G. K. 1977. Catalogue des Hélminthes des Amphibies en Bulgarie. Université de Plovdiv "P Hilendarski," Plovdiv, Bulgaria. 53 pp.

Buchvarov, G. K. 1983. Apport l'etude de helminthofaune des Amphipies sons queue (Amphibia-Ecadata) Du bassin de fleuve de la strouma. Nachne Trudove, Université de Plovdiv "Paissi Hilendarski." Travaux Scientifiques 21:373-380.

Buchvarov, G. K., D. Kirin, and A. Kostadinova. 2000. Platyhelminthes parasite assemblages in two species of snakes Natrix natrix and Natrix tessellata (Reptilia: Colubridae) from Bulgaria: seasonal variation. Journal of Environmental Protection and Ecology 1:124-131.

Bursey, C. R., S. R. Goldberg, and J. B. Bettaso. 2010. Persistence and stability of the component helminth community of the foothill yellow-legged frog, Rana boylii (Ranidae), from Humboldt County, California, 1964-1965, versus 2004-2007. American Midland Naturalist 163:476-482.

Cedhagen, T. 1988. Endoparasites in some Swedish amphibians. Acta Parasitologica Polonica 33:107-113.

Chikhlaev, I. V., A. I. Fayzulin, and R. I. Zamaletdinov. 2009. Data on the helminths of edible frog Rana esculenta Linnaeus, 1758 (Anura, Amphibia) in Middle-Volga region. Volga Ecological Journal 3:270-274.

Cipriani, P., S. Mattiucci, M. Paoletti, M. Santoro, and G. Nascetti. 2012. Rhabdias esculentarum n. sp. (Nematoda: Rhabdiasidae) from green frogs of the Rana esculenta species complex in Italy: molecular evidence, morphological description and genetic differentation from its congeners in frogs and toads. Systematic Parasitology 82:131-146.

Combes, C., and M. T. Gerbeaux. 1970. Recherches ecoparasitologiques sur l'helminthofaune de Rana ridibunda perezi (Amphibien, Anoure) dans l'est des Pyrenees. Vie et Milieu. Serie C; Biologie Terrestre 21: 121-158.

Corn, P. S. 2000. Amphibian declines: review of some current hypotheses. Pages 633-696 in D. W. Sparling, G. Linder, and C. A. Bishop, eds. Ecotoxicology of Amphibians and Reptiles. SETAC Press, Pensacola, Florida.

Cox, F. E. G. 1971. Parasites of British amphibians. Journal of Biological Education, 5:35-51.

Cushman, S. A. 2006. Effects of habitat loss and fragmentation on amphibians: a review and prospectus. Biological Conservation 128:231-240.

Daszak, P., A. A. Cunningham, and A. D. Hyatt. 2000. Emerging infectious diseases of wildlife: threats to biodiversity and human health. Science 287:443-449.
Daszak, P., L. Berger, A. A. Cunningham, A. D. Hyatt, D. E. Green, and R. Speare. 1999. Emerging infectious diseases and amphibian population declines. Emerging Infectious Diseases 5:735-748.

Davis, G. 1996. Collections of biological specimens essential for science and society. Association of Systematics Collections Newsletter 24:77-78, 88-90.

Dely, O. Gy. 1981. Amphibians and reptiles of the Hortobágy. Pages 387-389 in S. Mahunka, ed. The fauna of the Hortobágy National Park. Hungarian Natural History Museum, Budapest.

Düsen, S. 2007. Helminths of the two mountain frogs, banded frog, Rana camerani Boulenger, 1886 and Uludağ frog Rana macrocnemis Boulenger, 1885 (Anura: Ranidae), collected from the Antalya Province. Türkiye Parazitoloji Dergisi 31:84-88.

Düsen, S. 2012. First data on helminthfauna of the locally distributed mountain frog, "tavas frog," Rana tavasensis Baran and Atatür, 1986 (Anura: Ranidae), from inner-west Anatolia Region, Turkey. Turkish Journal of Zoology 36:496-502.

Düsen, S., and M. C. Oguz. 2010. Metazoan endoparasites of three species of anurans collected from the Middle Black Sea Region of Turkey. Helminthology 47: 226-232.

Düsen, S., and M. Öz. 2004. Helminth parasites of the tree frog, Hyla arborea (Anura: Hylidae) from southwest Turkey. Comparative Parasitology 71:258-261.

Düsen, S., and M. Öz. 2006. Helminths of the marsh frog, Rana ridibunda Pallas, 1771 (Anura: Ranidae), from Antalya Province, southwestern Turkey. Comparative Parasitology 73:121-129.

Düsen, S., I. H. Ugartas, A. Aydogdu, and M. C. Oguz. 2009. The helminth community of the agile frog, Rana dalmatina Bonaparte, 1839 (Anura: Ranidae) collected from northwest of Turkey. Helminthologia 46: 177-182.

Ecsedi, Z. 2004. A Hortobágy Madárvilága. Hortobágy Természetvédelmi Egyesület, Winter Fair, Balmazújváros-Szeged, Hungary. 588 pp.

Edelényi, B. 1942. A Szeged környéki békák belső élősködő férgei. Állattani Közlemények 39:1-21.

Edelényi, B. 1960. Adatok Eger és Hajduszoboszló környékén élő békák belsô élősködő férgeinek ismeretéhez. Egri Pedagógiai Fôiskola Évkönyve 6:343-358.

Edelényi, B. 1972. Mételyélősködők a Hortobágy vadonélő gerinceseiből. Debreceni Déry Múzeum Évkönyve 1972:5-34.

Endo, N., K. Sato, and Y. Nogata. 2009. Molecular based method for the detection and quantification of larvae of the golden mussel Limnoperna fortunei using real-time PCR. Plankton and Benthos Research 4:125-128.

Fernandez, J. P., J. A. Raga, E. Carbonell, and C. Rodriguez-Babio. 1986. Sobre algunos platelmintos hallados en anfibios del genero Bufo (L.). Miscellania Zoologica Barcelona 10:61-64.

Frandsen, F. 1974. A study of Danish amphibian parasite fauna. Acta Parasitologica Polonica 22:49-66.

Galli, P., G. Crosa, A. Gentilli, and M. Santagostino. 2001. New geographical records of parasitic nematodes from Bufo bufo in Italy. Parassitologia 43:147-149.

Galli, P., A. Gentilli, M. Santagostino, and G. Crosa. 2000. Parasites community from Bufo bufo killed by traffic. Pages 81-84 in Third Conference Safeguard the 
Amphibians, 23-24 June 2000, Lugano, Cantone Ticino, Switzerland

Goeze, J. A. E. 1782. Versuch einer Naturgeschichte der Eingeweidewürmer thierischer Körper. Pape, Blankenberg, Germany. $471 \mathrm{pp}$.

Global Taxonomy Initiative. 1999. Using systematic inventories to meet country and regional needs. A Report of the DIVERSITAS/Systematics Agenda 2000 International Workshop, 17-19 September 1998, American Museum of Natural History. The Center for Biodiversity and Conservation, American Museum of Natural History, $34 \mathrm{pp}$

Grabda-Kazubska, B., and J. Lewin. 1989. The helminth fauna of Bombina bombina (L.) and Bombina variegata (L.) in Poland. Acta Parasitologica Polonica 34: 273-279.

Graf, J. D., and M. Polls-Pelaz. 1989. Evolutionary genetics of the Rana esculenta complex. Pages 289302 in R. M. Dawley and J. P. Bogart, eds. Evolution and Ecology of Unisexual Vertebrates. The New York State Museum, Albany, New York.

Hassan, H. F., and I. S. Saeed. 2001. Light and electron microscope studies on the adult of Pleurogenoides medians (Ollson, 1876) (Trematoda: Lecithodendriidea) from Iraqui marsh frog Rana ridibunda. Bulletin of the Iraq Natural History Museum 9:35-41.

Hauswaldt, J. S., M. Höer, M. Ogielska, D. G. Christiansen, D. Dziewulska-Szwajkowska, E. Czernicka, and M. Vences. 2012. A simplified molecular method for distinguishing among species and ploidy levels in European water frogs (Pelophylax). Molecular Ecology Resources 12:797-805.

Hilbers, D. 2008. The nature guide to Hortobágy and the Tisza river floodplain, Hungary. No. 7, Crossbill Guides Foundation, Arnhem, Netherlands. 191 pp.

Hoberg, E. P. 1997. Phylogeny and historical reconstruction: host-parasite systems as keystones in biogeography and ecology. Pages 243-261 in M. Reaka-Kudla, D. E. Wilson, and E. O. Wilson, eds. Biodiversity II: Understanding and Protecting Our Biological Resources. Joseph Henry Press, Washington, D.C.

Hoberg, E. P. 2010. Invasive processes, mosaics and the structure of helminth parasite faunas. Revue Scientifique et Technique Office International des Épizooties 29:255-272.

Hoberg, E. P., and D. R. Brooks. 2008. A macroevolutionary mosaic: episodic host switching, geographical colonization and diversification in complex hostparasite systems. Journal of Biogeography 35:15331550.

Hoberg, E. P., and D. R. Brooks. 2010. Beyond vicariance: integrating taxon pulses, ecological fitting and oscillation in evolution and historical biogeography. Pages $7-$ 10 in S. Morand and B. Kransow, eds. The Geography of Host-Parasite Interactions. Oxford University Press, Oxford, U.K.

Hoberg, E. P., and D. R. Brooks. 2013. Episodic processes, invasion, and faunal mosaics in evolutionary and ecological time. Pages 199-213 in K. Rohde, ed. The Balance of Nature and Human Impact. Cambridge University Press, Cambridge, U.K.

Hoberg, E. P., K. E. Galbreath, J. A. Cook, S. J. Kutz, and L. Polley. 2012. Northern host-parasite assemblages: history and biogeography on the borderlands of episodic climate and environmental transition. Advances in Parasitology 79:1-97.

Hoberg, E. P., S. J. Kutz, J. A. Cook, K. Galaktionov, V. Haukisalmi, H. Henttonen, S. Laaksonen, A. Makarikov, and D. M. Marcogliese. 2013. Parasites. Pages 477-505 in H. Meltofte, ed. Arctic Biodiversity Assessment-Status and Trends in Arctic Biodiversity. Conservation of Arctic Flora and Fauna, Arctic Council, Akureyri, Iceland.

Hristovski, N., S. Smilkov, D. Tomovska, E. Popovich, and D. Kostich. 2006. Helmintofauna of Rana kurtmuelleri Gayda, 1940 syn. Rana balcanica Shneider et Sinish, 1992 (Anura: Ranidae) from Dojran Lake, Makedonia and Greece. 10th International Congress on the Zoogeography and Ecology of Greece and Adjacent Regions Patras, Greece, 26-30 June 2006.

Kirin, D. 2002. Biodiversity and Trematoda assemblages in Rana ridibunda Pallas from the district of Troyan Town. Experimental Pathology and Parasitology 5:712.

Kolendo, A. 1959. Helminthofauna of the green toad Bufo viridis Laurenti in the Lubin Palatinate. Acta Parasitologica Polonica 7:431-439.

Kopriva, J. 1957. Trematodes of frogs in Czechoslovakia. Ceskoslovenske Parasitology 4:191-199.

Kozák, A. 1966. Helminth fauna of frogs from the surroundings of Kosice. Biologia (Bratislava) 21:606611.

Kozák, A. 1968. Zur Saisondynamik der Helminthofauna des Wasserfrosches Rana esculenta L. Biologia (Bratislava) 23:872-876.

Kozák, A. 1973. Die Trematodenfauna des darpathengebietes der CSSR. Biologia (Bratislava) 28:335-350.

Kuc, I., T. Sulgostowska. 1988a. Helminth fauna of Rana ridibunda Pallas, 1771 from Goclawski Canal in Warszaw (Poland). Acta Parasitologica Polonica 33: 101-105.

Kuc, I., T. Sulgostowska. 1988b. Helminth fauna of frogs in the forests of Kampinos near Warszawa. Acta Parasitologica Polonica 33:267-272.

Kuzmin, Y. 2013. Review of Rhabdiasidae (Nematoda) from the Holarctic. Zootaxa 3639:1-76.

Lewin, J. 1992. Parasites of the sand lizard (Lacerta agilis L.) in Poland. Acta Parasitologica 37:19-24.

Locke, S. A., J. D. McLaughlin, S. Dayanandan, and D. J. Marcogliese. 2010. Diversity and specificity in Diplostomum spp. metacercariae in freshwater fishes revealed by cytochrome $\mathrm{c}$ oxidase I and internal transcribed spacer sequences. International Journal for Parasitology 40:333-343.

Locke, S. A., J. D. McLaughlin, A. R. Lapierre, P. T. J. Johnson, and D. J. Marcogliese. 2011. Linking the larvae and adults of Apharyngostrigea cornu, Histeromorpha triloba, and Alaria mustelea (Diplostomoidea: Digenea) using molecular data. Journal of Parasitology 97:846-851.

Manter, H. W. 1966. Parasites of fishes as biological indicators of recent and ancient conditions. Pages 5971 in J. E. McCauley, ed. Host-Parasite Relationships. Oregon State University Press, Corvallis, Oregon.

Marcogliese, D. J. 2005. Parasites of the superorganism: are they indicators of ecosystem health? International Journal for Parasitology 35:705-716. 
Marcogliese, D. J., and D. K. Cone. 1997. Parasite communities as indicators of ecosystem stress. Parassitologia 39:227-232.

Mashaii, N. 2005. Helminth parasites of green toad, Bufo viridis (Anura: Bufonidae), tree frog, Hyla arborea savignyi (Anura: Hylidae), and marsh frog, Rana ridibunda ridibunda (Anura: Ranidae) from southwest of Iran. Iranian Journal of Veterinary Research 6: $67-73$.

Mészáros, B., and L. Bartos. 1978. The karyological investigation of the three ranid species (Rana esculenta L., $R$. lessonae Cam., $R$. ridibunda Pall.) to be found in Hungary. Acta Biologica Debrecina 15:239-256.

Mihalca, A. D., G. Gherman, I. Ghira, and V. Cozma. 2007. Helminth parasites of reptiles (Reptilia) in Romania. Parasitology Research 101:491-492.

Minteer, B. A., J. P. Collins, K. E. Love, and R. Puschendorf. 2014. Avoiding (re)extinction. Science 344:260.

Moszczynska, A., S. A. Locke, J. D. McLaughlin, D. J. Marcogliese, and T. J. Crease. 2009. Development of primers for the mitochondrial cytochrome c oxidase I gene in digenetic trematodes (Platyhelminthes) illustrates the challenge of barcoding parasitic helminths. Molecular Ecology Resources 9:75-82.

Murai, É., T. Sulgostowska, I. Matskási, F. Mészáros, and K. Molnár. 1983. Parasitic helminths of vertebrates (fishes, amphibians, reptiles, and birds) in the Hortobágy National Park. Pages 15-30 in S. Mahunka, ed. The Fauna of the Hortobágy National Park, Budapest. Akadémia Kiadó, Budapest, Hungary.

Murvanidze, L., K. Nikolaishvili, and T. S, Lomidze. 2008. The annotated list of amphibian helminths of Georgia. Proceedings of the Institute of Zoology 23: 43-49.

Oguz, M. C., F. N. Altunel, and I. H. Ugurtas. 1994. An investigation of the species of platyhelminthes and Acanthocephalus ranae (Schrank 1788, Echinorhynchidae, Acanthocepahala) of marsh frogs (Rana ridibunda Pallas, 1771) which were collected from the Bursa and Edirne regions. Turkish Journal of Zoology 18:47-51.

Olsson, P. 1876. Bidrag till Skandinaviens helminthfauna. Kongl Svenska Vetenskaps Academiens Handlingar 14:2-35.

Popiolek, M., B. Rozenblut-Koscisty, M. Kot, W. Nosal, and M. Ogielska. 2011. Endoparasitic helminths of water frog complex in Poland: do differences exist between the parental species Pelophylax ridibundus and Pelophylax lessonae, and their natural hybrid Pelophylax esculentus? Helminthologia 48:108-115.

Popovic, E., and M. Mikes. 1989. Infestation of tailless amphibians of genus Rana by trematodes in the valley of the Tisa River (Yugoslavia). Tiscia 23:77-85.

Prokopic, J., and K. Krivanec. 1975. Helminths of amphibians, their interaction and host- parasite relationships. Acta Scientiarum Naturalium Academiae Scientiarum Bohemicae Brno 9:1-48.

Prosser, S. W. J., M. G. Velarde-Aguilar, V. LeónRégagnon, and P. D. N. Hebert. 2013. Advancing nematode barcoding: a primer cocktail for the cytochrome $\mathrm{c}$ oxidase subunit I gene from vertebrate parasitic nematodes. Molecular Ecology Resources 13: $1108-1115$.
R Core Team. 2013. R: a language and environment for statistical computing. R Foundation for Statistical Computing, Vienna, Austria. http://www.R-project. org/.

Rodrigues, H. O., S. S. Rodrigues, and R. Cristofaro. 1973. On the trematode parasites of Rana esculenta L. in metropolitan Portugal. Atas da Sociedade de Biologia do Rio de Janeiro 16:47-52.

Rózsa, L., J. Reiczigel, and G. Majoros. 2000. Quantifying parasites in samples of hosts. Journal of Parasitology $86: 228-232$.

Rudolphi, C. A. 1819. Entozoorum Synopsis cui Accedunt Mantissa Duplex et Indices Locupletissimi. Augusti Rücker, Berlin, Germany. $811 \mathrm{pp}$.

Ryzhikov, K. M., V. P. Sharpilo, and N. N. Shevchenko. 1980. Helminty Amphibiy Fauny SSSR. Nauka, Moskwa, Russia. 278 pp.

Saglam, N., and H. Arikan. 2006. Endohelminth fauna of the marsh frog Rana ridibunda from Lake Hazar, Turkey. Diseases of Aquatic Organisms 72:253-260.

Sey, O. 1964. Studies on the parasitic worms of Hungary I. Trematodes from amphibians and reptiles. A Pécsi Tanárképző Főiskola Tudományos Közleményei 1: 413-437.

Sey, O. 1968. Contributions to the fauna of parasitic worms breeding on the vertebrates of Bakony. A Veszprém Megyei Múzeumok Közleményei 7:315-326.

Sey, O. 1983. Reconstruction of the systematics of the family Diplodiscidae Skrjabin, 1949 (Trematoda: Paramphistomata). Parasitologia Hungarica 16:63-89.

Sey, O. 1991. The amphistomes of Hungarian vertebrates. Parasitologia Hungarica 24:59-68.

Sey, O., and K. Eöry. 1992. Helminth parasites of amphibians of the Lake Balaton area. Miscellanea Zoologica Hungarica 7:5-8.

Sharpilo, V. P., V. Biserkov, A. Kostadinova, J. M. Behnke, and Y. I. Kuzmin. 2001. Helminths of the sand lizard, Lacerta agilis (Reptilia, Lacertidae), in the Palaearctic: faunal diversity and spatial patterns of variation in the composition and structure of component communities. Parasitology 123:389-400.

Shimalov, V. V., and V. T. Shimalov. 2000. Helminth fauna of snakes (Reptilia, Serpentes) in Belorussian Polesye. Parasitology Research 86:340-341.

Shimalov, V. V., and V. T. Shimalov. 2001. Helminth fauna of toads in Belorussian Polesie. Parasitology Research $87: 84$.

Shimalov, V. T., V. V. Shimalov, and A. V. Shimalov. 2000. Helminth fauna of lizards in the southern part of Belarus. Parasitology Research 86:343.

Shimalov, V. V., V. T. Shimalov, and A. V. Shimalov. 2001. Helminth fauna of newts in Belarusian Polesie. Parasitology Research 87:356.

Tkach, V. V., Y. Kuzmin, and S. D. Snyder. 2014. Molecular insight into systematics, host associations, life cycles and geographic distribution of the nematode family Rhabdiasidae. International Journal for Parasitology 44:273-284.

Tkach, V. V., D. T. J. Littlewood, P. D. Olson, J. M. Kinsella, and Z. Swiderski. 2003. Molecular phylogenetic analysis of the Microphalloidea Ward, 1901 (Trematoda: Digenea). Systematic Parasitology 56: $1-15$. 
Tkach, V. V., J. Pawlowski, J. Mariaux. 2000. Phylogenetic analysis of the suborder Plagiorchiata (Platyhelminthes, Digenea) based on partial lsrDNA sequences. International Journal of Parasitology 30:83-93.

Vashetko, E. V., and B. H. Siddikov. 1999. The effect of the ecology of toads on the distribution of helminths. Turkish Journal of Zoology 23:107-110.

Vojtková, L. 1961. Notes on the helminth fauna of frogs from the Komarno area. Biologia (Bratislava) 16:25-30.

Vojtková, L. 1963. Zur kenntnis der helminthenfauna der schwanzlurchen (Urodela) der Tschechoslovakei. Vestnik Ceskoslovenske Spolecnosti Zoologicke 27:20-30.

Vojtková, L., and K. Krivanec. 1970. The helminth fauna of frogs from Moravia. Spisy Prirodovedecke Fakulty University J. E. Purkyne Brne 515:253-281.

Vojtková, L., F. Moravec, and L. Nabelkova. 1963. On the recent stage of investigation of the amphibian helminth fauna of CSSR. Casopis Narodniho Musea. Oddil Prirodovendny 9:121-131.

Vojtková, L., and J. Vojtek. 1975. Die Trematoden der amphibian inder Tschechowakei (Motolice Obojzivelniku CSSR). II. Larval stadian (mesocercariana und metacercarien). Folia Biologica 15:1-86.

Walton, A. C. 1933. The Nematoda as parasites of Amphibia. Journal of Parasitology 20:1-33.
Yildirimhan, H. S., C. R. Bursey, and S. R. Goldberg. 2006. Helminth parasites of the taurus frog, Rana holtzi, and the Uludağ frog, Rana macrocnemis, with remarks on the helminth community of Turkish anurans. Comparative Parasitology 73:237-248.

Yildirimhan, H. S., C. R. Bursey, and S. R. Goldberg 2009. Helminth parasites of the Caucasian parsley frog, Pelodytes caucasicus, from Turkey. Comparative Parasitology 76:247-257.

Yildirimhan, H. S., S. R. Goldberg, C. R. Bursey. 2006. Helminth parasites of the banded frog Rana camerani (Ranidae) from Turkey. Comparative Parasitology 73 : 222-236.

Yildirimhan, H. S., N. Sümer, S. Incedogan, and C. R. Bursey. 2012. Helminth parasites of the lemon-yellow tree frog Hyla savigny (Hylidae) from Turkey. Turkish Journal of Zoology 36:171-184.

Yildirimhan, H. S., I. H. Ugurtas, and F. N. Altunel. 1996. Rana ridibunda Pallas, 1771 (Ova Kurbagasi)'nin helmintleri üzerinde bir arastirma. Türkiye Parazitoloji Dergisi 20:113-130.

Yildirimhan, H. S., I. H. Ugurtas, and F. N. Altunel. 1997. An investigation on parasitic helminths of Rana macrocnemis Boulenger, 1885 (Uludağ frog). Turkish Journal of Zoology 21:467-473. 